International Journal of Instruction e-ISSN: 1308-1470 • www.e-iji.net

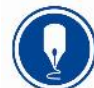

January $2022 \bullet$ Vol.15, No.1

p-ISSN: 1694-609X

pp. 547-564

Article submission code

20201005080743
Received: 05/10/2020

Revision: 14/07/202
Accepted: 09/08/2021

OnlineFirst: 08/11/2021

\title{
MURRDERR Strategy: Developing Creative Characters of Elementary School Prospective Teachers
}

\section{Maulana}

Universitas Pendidikan Indonesia, Indonesia, maulana@upi.edu.

\section{Aam Ali Rahman}

Universitas Pendidikan Indonesia, Indonesia,alirahman@upi.edu

\section{Mimih Aminah}

Sekolah Tinggi Keguruan dan Ilmu Pendidikan Sebelas April, Indonesia, mimih.aminah@yahoo.co.id

\begin{abstract}
Learning or lecturing, which are an essential part of the education process, are often presented only by cramming the teaching materials' contents to students but defying values. Allowing this to continue to happen will unquestionably lead to the next generation's increasingly tense situation, who are already in a messy condition and may lose their creative character. Along with character education that is always echoed, the presence of the MURRDERR strategy (Metaphor, Understand, Recall, Recognize, Detect, Elaborate, Review, and Respect) in classroom learning is expected to be one of the excellent and attractive choices for instilling lively characters in students. This paper provides a brief overview of the results of five semesters in total, including two semesters of applying the MURRDERR strategy in lectures at the Elementary Teacher Education Program, especially in mathematics lectures. Two research phases: first, didactic design research to produce teaching materials that can optimize the emergence of creative characters and followed by a quasi-experimental method. As a result, (1) the MURRDERR strategy provided a better contribution than conventional (expository/lecturing) learning in developing the creative character of students of the Elementary School Teacher Program, (2) teaching material developed through didactic design research was beneficial in achieving optimal learning outcomes, (3) students of the Elementary School Teacher Program with a background in science education tended to equip and prepare themselves to deal with issues related to creativity.
\end{abstract}

Keywords: character building, creative character, MURRDERR strategy, education, teaching, teacher 


\section{INTRODUCTION}

Education in Indonesia is currently in a feeble condition. The reality reported in many mass media shows the Indonesian character's weakening, which used to be very sturdy and firm. There has been an increase in cases of corruption, collusion, and nepotism. Shockingly, students are part of them: They defy the culture of shame and do immoral behavior. Not a few students who want to pass the "easy" way during the test try to find answers in an unethical way. The creative character of the youth generation seems to fade and eventually disappear. This generation's behavior, which is expected to be the next generation and agent of change, grows chaotic. Brawling, vandalizing, bullying, and doing other malfeasance things are happening among this generation. These critical characters lead to the disappearance of the title of a well-educated person.

Efforts that can be done to restore this generation are through proper education. The role of education is essential and central to develop all human potentials. It fosters lively characters and changes them gradually to a better generation, as it is affirmed in Undang-Undang Republik Indonesia Nomor 20 Tahun 2003 (the law) concerning the National Education System. National Education aims to develop capabilities and shapes the noble character and civilization of the nation to educate the life of the nation by developing the potential of students to become human beings of faith, to be devoted to God Almighty, noble, healthy, knowledgeable, capable, creative, independent, and become a democratic and responsible citizen.

Some research results on character education (e.g., Revell \& Arthur, 2007) state that every citizen needs to develop their creative character. For this reason, all education practitioners should share the responsibility to fulfill the mandate. Teachers are expected to provide space for the growth and development of students' creativity. It also requires efforts to create prospective teachers who have creative characters. In turn, the prospective teachers will develop the creative characters for all students they teach later.

As a further effort, developing teachers who have creative characters is assuredly the duty of lecturers, especially in the Elementary School Teacher Program, to roll out lessons that can provoke the emergence of lively characters. Various research concerning delivering lessons in Elementary School Teacher Program shows lecturers' predominance giving a lecture direct to the point without bridging or drill and practice. This way of lecturing results very teacher-centered, especially on explicit material as mathematics. Students with different educational backgrounds, roles passively and are unable to avoid the given lesson without having the opportunity to learn values that might be more important (Maulana et al., 2018, 2019; Ramdass \& Zimmerman, 2008; Reza, 2017).

Another effort is during the lesson itself. One alternative presentation to deliver is to use learning strategies, reiterating more on cognitive and affective. The learning strategy develops intellectual processes, along with a more qualified personality. The intended strategy is Metaphor-Understand-Recall-Recognize-Detect-Elaborate-Review-Respect or abbreviated in the acronym MURRDERR (Maulana et al., 2018, 2019). This strategy was adapted from another one, namely MURDER (Mood, Understand, Recall, 
Recognize, Detect, Elaborate, and Review) (Hythecker et al., 1988). This modification adds its strategic steps. It also aims to eliminate the impression of lofty because "murder" can be interpreted negatively.

\section{Creative Character}

Developing creative character as part of national education goals is of the many values regarding character education. By having creative character, students are expected to be able to complete their learning tasks creatively. They can analyze problems, become objective and fluent in investigating and expressing ideas, and develop flexibility in solving problems. Further, they can be motivated to grow collaborative thinking, to learn to question and not only to give answers but also to think multiperspective (Akgul \& Kahveci, 2016; Damayanti et al., 2018; Fatah et al., 2016; I. Isrokatun et al., 2018; Setyana et al., 2019; Sriwongchai et al., 2015; Supianti et al., 2019).

In mathematics education, the creative character, as referred to previously, is often referred to as a creative mathematical disposition, which is defined as a tendency to think and behave in creative ways (Saomi \& Sumarmo, 2018; Sumarmo \& NISHITANI, 2010; Wardani et al., 2011). The creative character indicators measured for this study were adopted from several experts and researchers (McClain \& Cobb, 2001; Saomi \& Sumarmo, 2018; Wardani et al., 2011; Yackel \& Cobb, 1996). It consists of: (a) sensing the problems and opportunities and willingly taking risks; (b) becoming sensitive to environmental situations and respecting the creativity of others; (c) more oriented toward the present and future than the past; (d) having self-confidence and independence; (e) having a great curiosity; (f) expressing and responding to feelings and managing emotions; (g) making various considerations; (h) respecting fantasy, rich in the initiative, having original ideas; (i) persevering and not quickly get bored, always having solution to solve problems.

\section{MURRDERR Strategy}

As discussed previously, the MURRDERR strategy (Metaphor, Understand, Recall, Recognize, Detect, Elaborate, Review, and Respect) (Maulana et al., 2018, 2019) is a modification of the MURDER strategy (Mood, Understand, Recall, Recognize, Detect, Elaborate, and Review) (Hythecker et al., 1988). The phases carried out in the MURRDERR strategy will be described below.

The first step is a Metaphor. It can be done at the beginning, middle, or the end of a lecture. The aim is to gain interest, maintain motivation, and develop students' character through a set of values in a relevant manner. In the learning process, metaphors act as triggers for creating students' interests, motivation, and positive thinking. They bring students into an atmosphere full of excitement, novelty, solemn appreciation that creates a meaningful context in the next learning process (DePorter et al., 1999). This intent understanding process of the values is eminently influential in instilling the strong nation's character to students. This Metaphor is not defined as language style or figurative language, but rather toward the presentation of self-development concepts and success figures. They can also describe a life that students will experience, a simulation, or the stories of various successful figures as in biography and other legends (Maulana 
et al., 2018, 2019). Giving a Metaphor during the learning session will impact each student to have more insight into their real-life. Students are expected to recognize their potential better and attach a positive character. It may raise their motivation to focus more on learning.

The next step is Understand - knowing the problem by reading parts of the material from the text without memorizing it. It continues to Recall - remembering/recounting; Recognize - sorting out, one group member gave an oral presentation of the material he had learned; Detect - checks, carried out by other members for the errors or omissions of the material, or perhaps differences in views that occur among members. Further, the sixth step is Elaborate - detailing, all steps from 2 to 5 are repeated for the next part of the material by a fellow partner; followed by Review - considering, or interpreting the results of their work, and transmitting it to other pairs in the group before presenting it in the class discussion. The final step is Respect - respecting; in this case, each student appreciates each other during the presentation.

The simple phases of the "MURRDERR" strategy, which are a further development from the ideas of previous experts (DePorter et al., 1999; Hythecker et al., 1988), are presented as follow:

1. Metaphor Phase. Learning is more directed to set the right mood by giving relaxation and focusing on learning tasks.

2. Understand Phase. Learners are allowed to understand particular material from the text without memorizing it.

3. Recall and Recognize Phases. One group member gives an oral presentation by restating the material that has been read and understood.

4. Detect Phase. Members pay close attention to and criticize the errors, the omission of notes, or differences of opinion.

5. Elaborate Phase. Partners elaborate steps 2, 3, and 4, repeat for the next part of the material.

6. Review Phase. Learners review the results of their work and transmit them to other pairs in the group.

7. Respect Phase. Learners respect each other contribution.

Based on the previous description, it is decisive to conduct a study on using MURRDERR strategies and developed teaching materials through Didactic Design Research (DDR) in lecturing, especially in mathematics lecturing in Elementary School Teacher Program. It researches the impact of both strategies in creating higher quality learning, a character without defying values.

\section{METHOD}

This research was conducted through two stages: 1) the Preparation phase; 2) the Implementation phase. Teaching materials based on MURRDERR problem-based 
learning using Didactical Design Research (DDR) were developed in the preparation stage. DDR is a research methodology developed from tacit didactical and pedagogical knowledge (Artigue, 2009; Hudson, 2008; Prediger \& Zwetzschler, 2013; Suryadi, 2013).

This DDR has three stages (Suryadi, 2013):

1. Lecturers carry out didactic Situation Analysis (DSA) to develop teaching materials before being tested in lessons. It synthesizes lecturers' thoughts about the various possibilities of student responses predicted to occur during lessons and anticipatory steps.

2. Methapedadidactic Analysis (MA) is conducted by lecturers before, during, and after the trial of teaching. Lecturers can observe lessons comprehensively, identify and analyze essential things occurring, and take quick and appropriate actions (scaffolding) to overcome learning obstacles so that the learning stages can run smoothly for optimal learning outcomes.

3. Lecturers conduct retrospective Analysis (RA) after the trial of teaching materials. The result of RA is utilized to do revisions of teaching materials that have been developed previously so that an ideal teaching material can be produced: teaching materials that fit the needs of students, that can predict and anticipate any learning obstacles so that the learning stages can run smoothly for optimal learning outcomes.

This preparation stage is the revised teaching materials of the MURRDERR strategy that is ideal for the lessons. After the optimal MURRDERR strategy was obtained, the research conducted research using a quasi-experimental method to design a nonequivalent control group design. Since samples were not randomly taken, and complete control of samples could not be done, the quasi-experimental method was used (Fraenkel et al., 1993).

This research population is the Elementary School Teacher Program students at State Universities in West Java and Banten Provinces, Indonesia. Six Universities participated in this research. From this population, 119 samples were taken distributed into three groups. The first group was given the MURRDERR strategy with DDR teaching materials (M-DDR), the second group was given the MURRDERR strategy (M), and the third group received conventional learning activities (C).

\section{FINDINGS AND DISCUSSION}

Table 1 illustrates that at first, the creative character in the three groups was not too much different, even though the control group applying conventional learning was slightly superior to the other two groups. Generally, it can be seen that there are differences in the achievement of students' creative characters between them. In this case, the achievement of creative character in the M-DDR group is higher than the M group, and the $\mathrm{M}$ group's achievement is higher than the $\mathrm{C}$ group. The significant increase in creative character, which was 0.24 , followed by the $\mathrm{M}$ class by 0.17 . However, the lowest was achieved in the $\mathrm{C}$ group, with an average increase of 0.04 . The 
science group's initial creative character is higher than the non-science group from the educational background, from all groups: $\mathrm{M}-\mathrm{DDR}, \mathrm{M}$, and $\mathrm{C}$.

Table 1

Creative character data

\begin{tabular}{|c|c|c|c|c|c|c|c|c|c|c|c|}
\hline \multirow{2}{*}{ Factor } & \multirow{2}{*}{ Group } & \multirow{2}{*}{ Statistic } & \multicolumn{3}{|c|}{ M-DDR } & \multicolumn{3}{|l|}{ M } & \multicolumn{3}{|l|}{$\mathrm{C}$} \\
\hline & & & Pre & Post & $\langle g\rangle$ & Pre & Post & $\langle g\rangle$ & Pre & Post & $\langle g\rangle$ \\
\hline \multirow{6}{*}{ 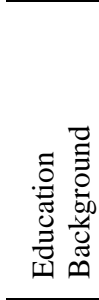 } & \multirow{3}{*}{ Science } & $n$ & 22 & & & 21 & & & 18 & & \\
\hline & & $\pi$ & 64,57 & 72,58 & 0,23 & 65,50 & 71,02 & 0,16 & 65,92 & 68,29 & 0,07 \\
\hline & & $s$ & 7,00 & 6,19 & 0,09 & 4,56 & 5,42 & 0,11 & 5,83 & 5,22 & 0,07 \\
\hline & \multirow{3}{*}{$\begin{array}{l}\text { Non- } \\
\text { Science }\end{array}$} & $n$ & 18 & & & 19 & & & 21 & & \\
\hline & & $x$ & 60,24 & 70,47 & 0,26 & 59,10 & 66,64 & 0,19 & 61,61 & 62,54 & 0,02 \\
\hline & & $s$ & 4,25 & 8,49 & 0,18 & 5,94 & 7,22 & 0,10 & 5,77 & 6,05 & 0,08 \\
\hline \multirow{3}{*}{ Total } & & $n$ & 40 & & & 40 & & & 39 & & \\
\hline & & $x$ & 62,62 & 71,63 & 0,24 & 62,46 & 68,94 & 0,17 & 63,60 & 65,19 & 0,04 \\
\hline & & $\bar{s}$ & 6,25 & 7,29 & 0,14 & 6,12 & 6,64 & 0,10 & 6,13 & 6,31 & 0,08 \\
\hline \multicolumn{3}{|c|}{$\begin{array}{l}\text { Note: } \\
\text { Ideal Score = } 100 \\
\text { Pre: Initial Score }\end{array}$} & $\langle g\rangle$ & & & & & & & & \\
\hline
\end{tabular}

Based on their educational background, the students' creative character achievement of the science group is still higher than the non-science group after the lessons. Further, DDR's use as teaching material tends to increase students' achievement compared to the conventional, especially in the non-science group. It can be seen on the average achievement of non-science background in the M-DDR group that is higher than $\mathrm{M}$ groups. The average increase in the creative character of M-DDR groups of science and non-science backgrounds was $22.50 \%$ and $25.91 \%$. The $\mathrm{M}$ science and non-science groups got an average increase of $16.05 \%$ and $18.80 \%$. While in the $\mathrm{C}$ groups for the science and non-science background, an average increase of $6.56 \%$ and $2.29 \%$ was obtained. The $\mathrm{C}$ group's science background had higher average scores than the nonscience background by analyzing the result. Besides, teaching materials using DDR contributed better than conventional teaching materials. As proven, the average increase in the science background's creative character in the M-DDR group is higher than the $M$ class and non-science background.

\section{The Creative Character Test Result in Pre-test for M-DDR, M, and C groups}

Because the normality and homogeneity of the variance have been fulfilled, the mean difference test will be carried out with one-way ANOVA to determine the differences of creative character for all groups. The result can be seen in Table 2. 
Table 2

One-way ANOVA for pre-test

\begin{tabular}{llllll}
\hline Prescale & Sum of Squares & df & Mean Square & F & Sig. \\
\hline Between Groups & 29.928 & 2 & 14.964 & .394 & .675 \\
\hline Within Groups & 4408.594 & 116 & 38.005 & & \\
\hline Total & 4438.523 & 118 & & & \\
\hline
\end{tabular}

From this test, the value of $\mathrm{F}=0.394$ and $\mathrm{Sig}=0.675>\alpha=0.05$ were obtained. Thus, the hypothesis stating that no difference $\left(\mathrm{H}_{0}\right)$ was accepted at the 0.05 significance level. It implies no difference in the three classes' initial creative character (M-DDR, M, C). In other words, before learning with a different approach was implemented, samples in all three groups had the same initial creative character. So, improvement after learning is identified as the impact of the different approaches implemented in those groups.

\section{The Creative Character Test Result in Pre-test for Science and Non-science Background}

The 119 samples were divided into 61 people with a scientific background; 58 others with a non-scientific background. Table 3 describes the pre-test score of creative characters based on these two groups of backgrounds. The results of the normality test through the Kolmogorov-Smirnov test (because the number of students in both groups is more than 50 people), obtained $p$-value $=0.179>\alpha=0.05$ for the science background, and p-value $=0.200>\alpha=0.05$ for non-science background. It indicates that the samples were normally distributed. While the Levene test results to determine the variance's similarity, obtained the value of $F=0.496$, and the probability value sig. $=0.483>0.05$, it can be said that the samples' initial creative character data is homogeny.

Table 3

Independent samples test: Samples' initial creative character based on background

\begin{tabular}{|c|c|c|c|c|c|c|}
\hline & \multicolumn{6}{|c|}{$\begin{array}{l}\text { Levene's } \\
\text { Test for } \\
\text { Equality } \\
\text { of } \\
\text { Variances t-test for Equality of Means }\end{array}$} \\
\hline & \multirow[b]{2}{*}{ Sig. } & & \multirow{2}{*}{$\begin{array}{l}\text { Sig. } \\
(2- \\
\text { tailed })\end{array}$} & \multirow{2}{*}{$\begin{array}{l}\text { Mean } \\
\text { Difference }\end{array}$} & \multirow{2}{*}{$\begin{array}{l}\text { Std. Error } \\
\text { Difference }\end{array}$} & $\begin{array}{l}95 \% \text { Confidence } \\
\text { Interval of the } \\
\text { Difference }\end{array}$ \\
\hline & & $\mathrm{df}$ & & & & Lower Upper \\
\hline $\begin{array}{l}\text { Prescale Equal variances } \\
\text { assumed }\end{array}$ & .496 .483 & 4.771117 & .000 & 4.93122 & 1.03351 & 2.884426 .97803 \\
\hline $\begin{array}{l}\text { Equal variances } \\
\text { not assumed }\end{array}$ & & 4.780116 .9 & .000 & 4.93122 & 1.03155 & 2.888296 .97416 \\
\hline
\end{tabular}

By using the t-test of two independent samples, the results obtained were sig. $=0,000<$ 0.05 . Thus, $\mathrm{H}_{0}$ that states there is no difference in the initial creative character, is 
rejected. It means that there are significant differences in the average creative character of students in the science and non-science background, where the average of the samples' creative character of science background (65.29) is higher than the non-science (60.36).

\section{The Creative Character Test Result in Post-Test for M-DDR, M, and C groups}

The final scale data's test results using the Shapiro-Wilk test concluded that the final creative character scale data in the three groups (M-DDR, M, and C) are normally distributed. Furthermore, the homogeneity test shows the final achievement of creative characters in the M-DDR, M, and C groups are homogenous at the significance level $\alpha=$ 0.05 . Henceforth, One-way ANOVA was conducted to obtain information on whether the differences occurred. If the test results show differences, finding out where the difference lies can be analyzed with the Scheffe test.

Table 4

ANOVA test result: The creative character post-test data based on groups

\begin{tabular}{llllll}
\hline & Sum of Squares & df & Mean Square & F & Sig. \\
\hline Between Groups & 825.264 & 2 & 412.632 & 9.022 & .000 \\
\hline Within Groups & 5305.298 & 116 & 45.735 & & \\
\hline Total & 6130.562 & 118 & & & \\
\hline
\end{tabular}

ANOVA test results presented in Table 4 give the value $\mathrm{F}=9.022$ with a probability value sig. $=0,000<\alpha=0.05$. Consequently, the hypothesis stating that there is no difference in means between the three groups $\left(\mathrm{H}_{0}\right)$ is rejected. There are significant differences in the creative character between M-DDR, M, and C groups. Further, the Scheffe test was employed to determine the differences in the achievement of creative character. The data presented in Table 5 for Multiple Comparisons in Scheffe shows that the average of the three groups' creative character is different. The M-DDR group is better than the $\mathrm{M}$ group; the $\mathrm{M}$ group is better than the $\mathrm{C}$ group.

Table 5

Multiple comparisons

Post scale: Scheffe

\begin{tabular}{|c|c|c|c|c|c|c|}
\hline \multirow[b]{2}{*}{$\begin{array}{l}\text { (I) Research } \\
\text { Class }\end{array}$} & \multirow[b]{2}{*}{$\begin{array}{l}\text { (J) Research } \\
\text { Class }\end{array}$} & \multirow[b]{2}{*}{$\begin{array}{l}\text { Mean } \\
\text { Difference (I-J) }\end{array}$} & \multirow[b]{2}{*}{ Std. Error } & \multirow[b]{2}{*}{ Sig. } & \multicolumn{2}{|c|}{$95 \%$ Confidence Interval } \\
\hline & & & & & $\begin{array}{l}\text { Lower } \\
\text { Bound }\end{array}$ & $\begin{array}{l}\text { Upper } \\
\text { Bound }\end{array}$ \\
\hline \multirow[t]{2}{*}{ PM-DDR } & $\mathrm{PM}$ & 2.69675 & 1.51221 & .208 & -1.0531 & 6.4466 \\
\hline & Conventional & $6.44041^{*}$ & 1.52187 & .000 & 2.6666 & 10.2142 \\
\hline \multirow[t]{2}{*}{$\mathrm{PM}$} & PM-DDR & -2.69675 & 1.51221 & .208 & -6.4466 & 1.0531 \\
\hline & Conventional & 3.74366 & 1.52187 & .052 & -.0301 & 7.5174 \\
\hline \multirow[t]{2}{*}{ Conventional } & PM-DDR & $-6.44041^{*}$ & 1.52187 & .000 & -10.2142 & -2.6666 \\
\hline & $\mathrm{PM}$ & -3.74366 & 1.52187 & .052 & -7.5174 & .0301 \\
\hline
\end{tabular}

*. The mean difference is significant at the 0.05 level. 
The results show that samples with problem-based learning using the MURRDERR strategy with DDR teaching material have significantly improved compared to samples with the conventional lesson. It provides information that the approach accompanied by teaching materials can reduce students' learning obstacles. To some extent, the strategy can make a considerable contribution to improving students' creative character.

\section{The Creative Character Test Result in Post-Test for Science and Non-science Background}

After all assumptions of normality and homogeneity of variance were met, the average difference test was carried out by (1) two-independent sample t-test for both science and non-science backgrounds, (2) One-way ANOVA test for science backgrounds in the class M-DDR, M, and C, and (3) One-way ANOVA test for non-science background in the M-DDR, $\mathrm{M}$, and $\mathrm{C}$ groups. If the ANOVA test results show differences, then a posthoc test with the Scheffe test to see where the differences are applied. The complete test results are presented in Table 6.

Based on Table 6 the test results were obtained in the form of t value $=3.509$ with $\mathrm{p}$ value $=0.001<\alpha=0.05$. This test concluded that the achievement of the two groups' creative character is significantly different. As for looking at the average value of the two groups, it can be said that the achievement of creative character in the science background (70.78) is better than the achievement of the non-science background (66.35). The average mean difference is 4.43. Through the One-way ANOVA test, the value of $\mathrm{F}$ is 2.888 , and sig is obtained through the One-way ANOVA test. $=0.064>\alpha$ $=0.05$. It understands that there is no difference in the achievement of creative character between students with science backgrounds in the M-DDR, M, and C groups.

Table 6

The mean differences of post-test result based on background

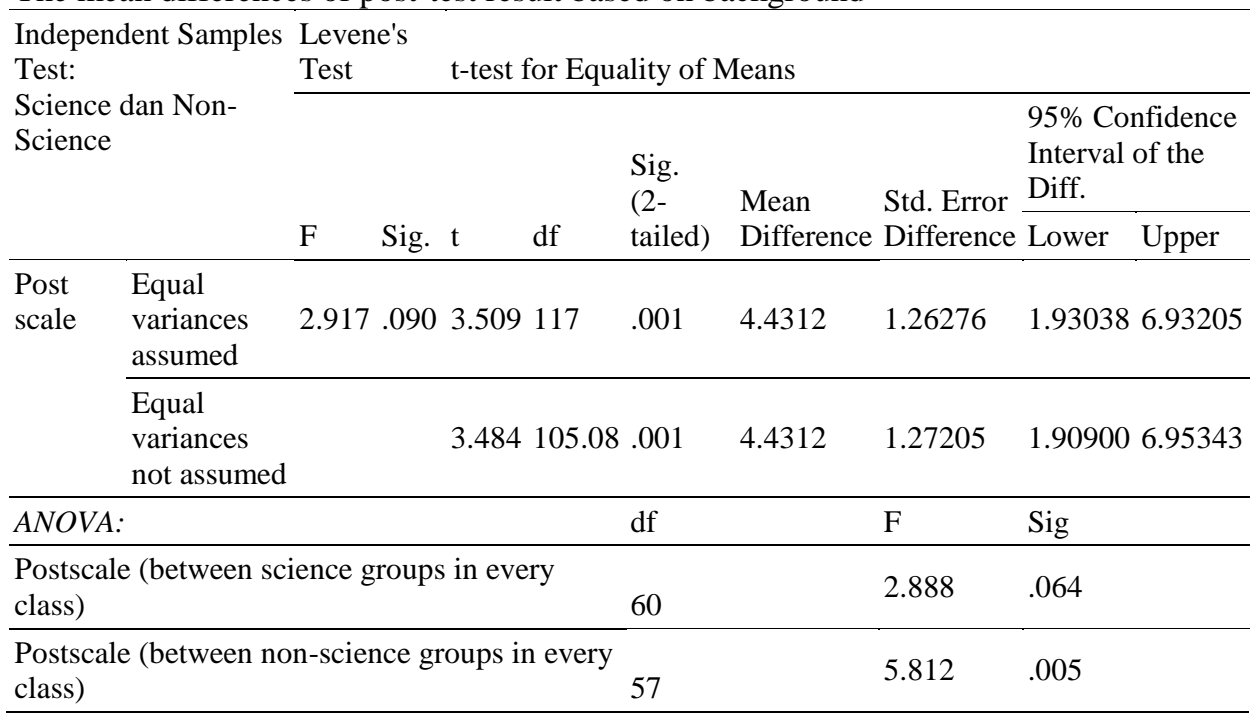


In contrast, $\mathrm{H}_{0}$ in non-science background was rejected: the value of $\mathrm{F}=5.812$ and sig. $=0.005<\alpha=0.05$. Thus, in non-science background samples, the achievement of creative character between M-DDR, M, and C groups was significantly different. Then, to see which group has different achievements, a Scheffe test was performed. As the results: (1) At the significance level $\alpha=0.05$, there was no difference in the achievement of students' creative character with non-science backgrounds in the M-DDR and $\mathrm{M}$ groups. The mean difference was only 3.83. (2) At the significance level $\alpha=0.05$, there was a significant difference in the achievement of samples' creative character with a non-science background between M-DDR and C groups with a mean difference of 7.93. It was proven that the achievement of the non-scientific group in the PM-DDR group was better than in the $C$ group. (3) At the significance level $\alpha=0.05$, there was no difference in the achievement of the creative character of samples with non-science backgrounds in the $\mathrm{M}$ and $\mathrm{C}$ groups. Also, the mean difference is only 4.10.

The above analysis results can be elaborated that the achievement of science and nonscience background samples' creative character has a significant difference. The science background is higher than the non-science background. Furthermore, science background samples in the M-DDR, $\mathrm{M}$, and $\mathrm{C}$ groups obtained no different achievements. Meanwhile, in the non-science background, problem-based learning with a MURRDERR strategy (especially with DDR teaching materials) impacted better achievement than the conventional approach.

\section{The Creative Character Test Result for Different Gain between M-DDR, M, and C Group}

The normality test results using Shapiro-Wilk obtained p-values for the M-DDR, M, and $\mathrm{C}$ were less than the significance level $\alpha=0.05$. It can be stated that the data gain of creative characters was not normally distributed. Therefore, to see the difference in the three groups' average gain, the Kruskal-Wallis test was used, followed by the Multiple Comparisons Between Treatments test.

Table 7

Kruskal-Wallis Test: Creative Character Gain

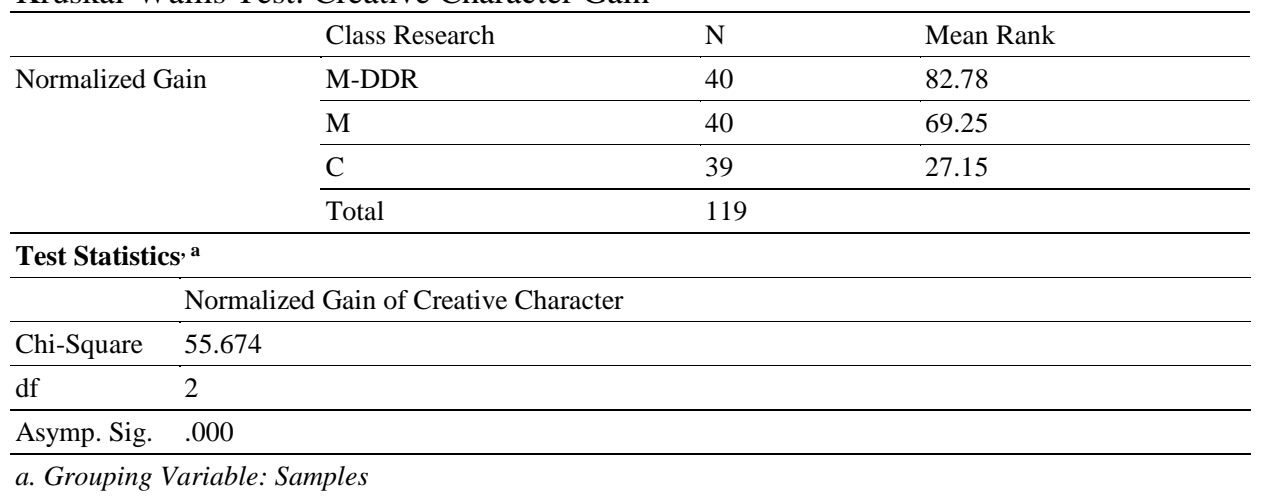


Based on the Kruskal-Wallis test in Table 7, it was proven that there were differences in the increase in the creative character of the three groups (Asymp. Sig =0,000). Multiple Comparisons between Treatments were used to identify the differences. It was tested by pairing M-DDR and M, M-DDR, and C, and between $\mathrm{M}$ and $\mathrm{C}$., The test results show that: (1) Increasing the M-DDR group's creative character and $M$ group was not significantly different. M-DDR groups got an increase of 0.24 while the M group 0.17 . The mean difference between the two was only 0.07. (2) Based on the mean rank, it can be seen that the increase in the creative character of the M-DDR group was better than the $\mathrm{C}$ group. The mean difference between the two groups was 0.20 . The test results (3) show a significant difference in increasing the $\mathrm{M}$ group and $\mathrm{C}$ group's creative character. In this case, the $M$ group's mean rank was better than the $C$ group, so the $M$ group's creative character improvement was higher than in the $\mathrm{C}$ group. The averages difference between the two was 0.13 .

The Creative Character Test Result for Different Gain between Science and NonScience Background.

The Normality test of creative character data for samples' educational background with a total of 61 and 58 students in science and non-science background was described as the following: Kolmogorov-Smirnov test for the gain of science groups obtained p-value = $0.200>0.05$ (normal distribution). Meanwhile, in the non-science group, a p-value $=$ $0.002<0.05$ (not normally distributed) was obtained. Therefore, a non-parametric test was used for two independent samples, using the U-test from Mann-Whitney.

Table 8

Mann-Whitney Test: Creative Character Gain Based on Background

\begin{tabular}{|c|c|c|c|c|}
\hline & Educational Background & $\mathrm{N}$ & Mean Rank & Sum of Ranks \\
\hline \multirow{3}{*}{$\begin{array}{l}\text { Normalized Gain of } \\
\text { Creative Character }\end{array}$} & Science & 61 & 62.03 & 3784.00 \\
\hline & Non-science & 58 & 57.86 & 3356.00 \\
\hline & Total & 119 & & \\
\hline \multicolumn{5}{|l|}{ Statistics Test ${ }^{\mathrm{a}}$} \\
\hline \multicolumn{5}{|c|}{ Normalized Gain of Creative Character } \\
\hline Mann-Whitney U & 1645.000 & & & \\
\hline Z & -.659 & & & \\
\hline Asymp. Sig. (2-tailed) & .510 & & & \\
\hline Eta Squared & .004 & & & \\
\hline
\end{tabular}

Based on the Mann-Whitney test results in Table 8, it was found that the Asymp.Sig value $=0.510>0.05$. It can be concluded that the increase in the creative character of samples between the science and non-science groups was not significantly different. It also is supported by the effect size calculation (eta squared) that shows $\eta^{2}=0.004$. Through the tests, it is known that the creative character of students in the science group was significantly better than the non-science group. Such differences can be caused 
because non-science group samples do not like mathematics (Hannula, 2002; Monteiro et al., 2017). Moreover, the tendency to think and behave mathematically in a science background is vaster, along with more experience in the level of education they have gone through. It is in line with the amount of intrinsic motivation possessed by a person and influences how he views things (Yaman et al., 2017).

Based on the achievement and improvement of creative character during the research, the M-DDR approach was significantly better than the conventional approach. Then, among students who obtained the M-DDR approach, they achieved the final achievement of creative character, which was slightly better than students in the $M$ group. Likewise, samples who obtained the $\mathrm{M}$ approach had a higher score of achieving creative character than students in the conventional group. The results of differences in the test of creative character gain in the three groups indicated that MURRDERR problem-based learning contributed more to samples than conventional learning.

In general, the rejection of the statistical hypothesis regarding differences in final achievement and improvement of creative character in the M-DDR, M, and C groups, led to the valuable finding that the treatment in the form of a learning approach had significantly different effects on samples. In the final achievement and the improvement of creative character, the test results proved that samples with M-DDR learning get the highest achievement and improvement, followed by samples in the M group, samples in the $\mathrm{C}$ group. These findings strengthen the previous research that problem-based learning can improve student learning outcomes in aspects of attitude, character, or what is referred to as disposition (Hendriana et al., 2018; Maskur, 2020; Merritt et al., 2017; Napitupulu et al., 2016; Şendă̆ \& Odabaş1, 2009). Also, teaching materials through DDR are better to anticipate student learning obstacles. It also is in line with student needs. As a result, samples using DDR teaching materials obtain better effective learning outcomes (Setiadi et al., 2017; Suryadi, 2013).

From the findings, it is also clear that $\mathrm{M}-\mathrm{DDR}$, $\mathrm{M}$, or $\mathrm{C}$ significantly improve prospective elementary school teachers' creative character. Even for conventional learning, which is often considered wrong, it contributes to the achievement and improvement of creative character. In other words, learning using any approach, as long as lecturers or teachers carry out their learning optimally according to the uniqueness of the method or approach, the opportunity to make students learn is also still very accessible. There will be changes in behavior, both at the cognitive and affective levels, which leads to a better direction (Chambers, 2017; Kark Smollan, 2006; Land \& Jonassen, 2012). However, the advantages of MURRDERR's learning strategy, especially those combined with teaching materials from didactic design research, contribute to the achievement and improvement of creative character better than relying solely on conventional approaches. This innovative effort, as the MURRDERR strategy, has to be developed further. Thus, the result of an investigation into one of the creative characters, self-efficacy, is needed as one of the professional competencies that must be possessed by a teacher, especially math teachers (Nurlu, 2017).

Given the result of final achievement and creative character improvement based on samples' educational background: science and non-science groups, it can be concluded 
as follows: First, creative character analysis using the t-test Mann-Whitney turns out that between the science and non-science groups have significant differences. In this case, the science group's achievement is convincingly higher than the non-science group's achievement. While the difference in the increase in the creative character, the results were obtained that samples with MURRDERR learning strategy, both with DDR and non-DDR teaching materials, apparently experienced an increase compared to conventional learning. Similarly happened to groups of students with non-science education backgrounds. Increasing the creative character of non-science group students in the experimental group was significantly better than the non-science group samples in the control class. It indicates that applying MURRDERR's problem-based learning to mathematics learning has a more significant impact than conventional approaches in enhancing creative character, even for non-science groups.

From the previous explanation and analysis, it can be concluded that the MURRDERR learning strategy has a significantly better influence than conventional learning. It develops the affective domain learning outcomes for Elementary School Teacher Programs, especially in the form of a tendency to think and act creatively towards mathematics, whether in science or non-science groups. This conclusion is in line with the previous research findings, which states that problem-based learning can increase students' tendency to get more interested, be more motivated, and be more active in learning, regardless of their background (Chung* \& Chow, 2004).

Another interesting finding is that the increase in the creative character of non-science groups in the M-DDR and $\mathrm{M}$ groups turned out to be significantly better than the science background in the $\mathrm{C}$ group. These findings indicate that the MURRDERR problem-based approach has significantly improved students' mathematical creative character, even for students with non-science backgrounds who get higher scores in the science group in the control class with conventional learning.

Moreover, the results of the research also provide information that the M-DDR group was increasing in general, but not significant, except for indicators: (1) be sensitive to the surrounding and respect the creativity of others; (2) be more oriented toward the present and future than the past; (3) has great curiosity and makes diverse considerations. Those factors got moderate improvement. Meanwhile, only one indicator got a moderate increase in the $\mathrm{M}$ group: be more oriented toward the present and future than the past. However, in the conventional class, almost all indicators experienced a low increase. Even for self-confidence and independence, there was no improvement in the average seen. In other words, conventional learning does not significantly impact the development of students' self-confidence and independence. In the conventional approach, the central role lies in the instructor's self, and the instructor is also seen as the primary source during learning (Afandi, 2018; Eviyanti et al., 2017; Widada et al., 2019). Students are not given enough space to do more activities, for example, asking questions or expressing ideas, so that the confidence that might exist cannot be adequately developed. Students are also accustomed to getting material that is indeed ready-made, so it raises the habit of receiving rather than being independent. It becomes 
a habit in learning, especially for students accustomed to thinking and beliefs conventionally or traditionally (Purnomo et al., 2017).

Furthermore, from all indicators of creative character, it is known that the average overall improvement occurring is low. In this case, that matters relating to the affective aspects require a relatively long time to develop because it requires: (1) a good understanding of the characters to be developed, (2) exemplary, (3) carried out continuously, and (4) the habituation, which all of them cannot be achieved instantly (e.g., Krosnick, 1989; Wilson et al., 1989).

\section{CONCLUSION}

In general, it can be concluded that the improvement of the creative character of students of the Elementary School Teacher Program using the MURRDERR strategy with or without didactical design research (DDR) is better than conventional learning. However, DDR can convincingly minimize the learning obstacles because it is suitably designed for specific teaching and learning. Hence, for students with different educational backgrounds, the influence on prospective teachers' creative character development cannot be ignored. Candidates with a science background are significantly better than non-science backgrounds to increase their creative character, especially in the mathematical domain. In other words, those who have a science background tend to equip and prepare themselves to deal with problems with creativity. Besides, the learning setting with the MURRDERR strategy provides a better influence in improving the creative character where students are "Told" instead of "finding out."

Research on efforts to improve this creative character should be continued with a broader population. It is not only applied to prospective elementary school teachers but also prospective secondary school teachers. With the increasing number of teachers who have creative characters, it is hoped that more students will be helped to build their creative character later on. So, this character will eventually become the core to build the nation.

\section{ACKNOWLEDGMENTS}

The author would like to thank Prof. Didi Suryadi and Prof. Utari Sumarmo for their excellent assistance in providing valuable input to this manuscript.

\section{REFERENCES}

Afandi, A. (2018). Difference of learning mathematics between open question model and conventional model. Malikussaleh Journal of Mathematics Learning (MJML), l(1), 13-18. https://doi.org/10.29103/mjml.v1i1.620

Akgul, S., \& Kahveci, N. G. (2016). A Study on the Development of a Mathematics Creativity Scale. Eurasian Journal of Educational Research, 62, 57-76. https://doi.org/10.14689/ejer.2016.62.5

Artigue, M. (2009). Didactical design in mathematics education. In Nordic research in mathematics education (pp. 5-16). Brill Sense. https://doi.org/10.1108/S1479- 


\section{3}

Chambers, D. (2017). Changing attitudes of pre-service teachers towards inclusion through service-learning. in service-learning. emerald publishing limited. https://doi.org/10.1108/S1479-363620170000012013

Chung*, J. C. C., \& Chow, S. M. K. (2004). Promoting student learning through a student-centred problem-based learning subject curriculum. Innovations in Education and Teaching International, 4l(2), 157-168. https://doi.org/10.1080/1470329042000208684

Damayanti, D. T., Sumarmo, U., \& Maya, R. (2018). Improving student's mathematical creative thinking ability and self regulated learning using sylver approach. (JIML) Journal Of Innovative Mathematics Learning, 1(3), 173-183. https://doi.org/10.22460/jiml.v1i3.p268-278

DePorter, B., Reardon, M., \& Singer-Nourie, S. (1999). Quantum teaching: Orchestrating student success. Prentice Hall.

Eviyanti, C. Y., Surya, E., Syahputra, E., \& Simbolon, M. (2017). Improving the students' mathematical problem solving ability by applying problem based learning model in VII grade at SMPN 1 Banda Aceh Indonesia. International Journal of Novel Research in Education and Learning, 4(2), 138-144. Retrieved from https://www.noveltyjournals.com/issue/IJNREL/Issue-2-March-2017-April-2017

Fatah, A., Suryadi, D., \& Sabandar, J. (2016). Open-ended approach: An effort in cultivating students' mathematical creative thinking ability and self-esteem in mathematics. Journal on Mathematics Education, 7(1), 11-20. https://doi.org/10.22342/jme.7.1.2813.9-18

Fraenkel, J. R., Wallen, N. E., \& Hyun, H. H. (1993). How to design and evaluate research in education (Vol. 7). McGraw-Hill New York.

Hannula, M. S. (2002). Attitude towards mathematics: Emotions, expectations and values. Educational Studies in Mathematics, 49(1), 25-46. https://doi.org/10.1023/A:1016048823497

Hendriana, H., Johanto, T., \& Sumarmo, U. (2018). The role of problem-based learning to improve students' mathematical problem-solving ability and self confidence. Journal on Mathematics Education, 9(2), 291-300. https://doi.org/10.22342/jme.9.2.5394.291300

Hudson, B. (2008). Didactical design research for teaching as a design profession. Teacher Education Policy in Europe: A Voice of Higher Education Institutions, 345. Retrieved from https://core.ac.uk/download/pdf/35126096.pdf

Hythecker, V. I., Dansereau, D. F., \& Rocklin, T. R. (1988). An analysis of the processes influencing the structured dyadic learning environment. Educational Psychologist, 23(1), 23-37. https://doi.org/10.1207/s15326985ep2301_2 
Isrokatun, I., Hanifah, N., \& Maulana, M. (2018). Acceptance finding ability. IOP Conference Series: Materials Science and Engineering, 434(1). https://doi.org/10.1088/1757-899X/434/1/012295

Kark Smollan, R. (2006). Minds, hearts and deeds: Cognitive, affective and behavioural responses to change. Journal of Change Management, 6(2), 143-158. https://doi.org/10.1080/14697010600725400

Krosnick, J. A. (1989). Attitude importance and attitude accessibility. Personality and Social Psychology Bulletin, 15(3), 297-308. https://doi.org/10.1177/0146167289153002

Land, S., \& Jonassen, D. (2012). Theoretical foundations of learning environments. Routledge. https://doi.org/10.4324/9780203813799

Maskur, R. (2020). The effectiveness of problem based learning and aptitude treatment interaction in improving mathematical creative thinking skills on curriculum 2013. European Journal of Educational Research, 9(1), 375-383. https://doi.org/10.12973/eu-jer.9.1.375

Maulana, M., Hanifah, N., Aeni, A. N., Julia, J., \& Syahid, A. A. (2019). Developing mathematical investigative attitudes of prospective primary school teachers. Journal of Physics: Conference Series, 1318(1). https://doi.org/10.1088/1742-6596/1318/1/012146

Maulana, M., Hanifah, N., Aeni, A. N., Julia, J., \& Syahid, A. A. (2018). MURRDERR strategy in developing mathematical investigation thinking skill of elementary school pre-service teacher. IOP Conference Series: Materials Science and Engineering, 434(1). https://doi.org/10.1088/1757-899X/434/1/012031

McClain, K., \& Cobb, P. (2001). An analysis of development of sociomathematical norms in one first-grade classroom. Journal for Research in Mathematics Education, 236-266. https://doi.org/10.2307/749827

Merritt, J., Lee, M. Y., Rillero, P., \& Kinach, B. M. (2017). Problem-based learning in K-8 mathematics and science education: A literature review. Interdisciplinary Journal of Problem-Based Learning, 11(2). https://doi.org/10.7771/1541-5015.1674

Monteiro, V., Peixoto, F., Mata, L., \& Sanches, C. (2017). Mathematics: I don t like it! I like it! Very much, a little, not at all... Social support and emotions in students from 2nd and 3rd cycles of education. Análise Psicológica, 35(3), 281-296. https://doi.org/10.14417/ap.1156

Napitupulu, E. E., Suryadi, D., \& Kusumah, Y. S. (2016). Cultivating upper secondary students' mathematical reasoning-ability and attitude towards mathematics through problem-based learning. Journal on Mathematics Education, 7(2), 117-128. https://doi.org/10.22342/jme.7.2.3542.117-128

Nurlu, Ö. (2017). Investigation of teachers' mathematics teaching self-efficacy. International Electronic Journal of Elementary Education, 8(1), 21-40. Retrieved from https://www.iejee.com/index.php/IEJEE/article/view/95 
Prediger, S., \& Zwetzschler, L. (2013). Topic-specific design research with a focus on learning processes: The case of understanding algebraic equivalence in grade 8 . Educational Design Research: Illustrative Cases, 407-424. Retrieved from https://www.mathematik.uni-dortmund.de/ prediger/veroeff/13-EDR-PredigerZwetzschler-Topic-Specific-Design-Research.pdf

Purnomo, Y. W., Suryadi, D., \& Darwish, S. (2017). Examining pre-service elementary school teacher beliefs and instructional practices in mathematics class. International Electronic Journal of Elementary Education, 8(4), 629-642. Retrieved from https://www.iejee.com/index.php/IEJEE/article/view/137

Ramdass, D., \& Zimmerman, B. J. (2008). Effects of self-correction strategy training on middle school students' self-efficacy, self-evaluation, and mathematics division learning. Journal of Advanced Academics, 20(1), 18-41. https://doi.org/10.4219/jaa-2008-869

Revell, L., \& Arthur, J. (2007). Character education in schools and the education of teachers. Journal of Moral Education, 36(1), 79-92. https://doi.org/10.1080/03057240701194738

Reza, S. A. M. (2017). Raising the quality of teaching through Kyouzai Kenkyuu - the study of teaching materials. International Journal for Lesson and Learning Studies, 6(1), 10-26. https://doi.org/10.1108/IJLLS-07-2016-0018

Saomi, A. S. N., \& Sumarmo, U. (2018). Relationship between matematic disposition and problem solving about mathematics. (JIML) Journal Of Innovative Mathematics Learning, 1(3), 240-242. https://doi.org/10.22460/jiml.v1i3.p335-337

Şendağ, S., \& Odabaşı, H. F. (2009). Effects of an online problem based learning course on content knowledge acquisition and critical thinking skills. Computers \& Education, 53(1), 132-141. https://doi.org/10.1016/j.compedu.2009.01.008

Setiadi, D. R., Suryadi, D., \& Mulyana, E. (2017). Didactical design enrichment of angle in geometry. J. Phys. Conf. Ser, 895(1), 12060. https://doi.org/10.1088/1742$6596 / 895 / 1 / 012060$

Setyana, I., Kusmayadi, T. A., \& Pramudya, I. (2019). Problem-solving in creative thinking process mathematics student's based on their cognitive style. Journal of Physics: Conference Series, 1321(2), 22123. https://doi.org/10.1088/1742$6596 / 1321 / 2 / 022123$

Sriwongchai, A., Jantharajit, N., \& Chookhampaeng, S. (2015). Developing the mathematics learning management model for improving creative thinking in thailand. International Education Studies, 8(11), 77-87. https://doi.org/10.5539/ies.v8n11p77

Sumarmo, U., \& Nishitani, I. (2010). High level mathematical thinking. 群馬大学教育 学部紀要 自然科学編，58,9-22. Retrieved from https://gair.media.gunmau.ac.jp/dspace/bitstream/10087/5130/1/03_Nishitani.pdf

Supianti, I. I., Kartasasmita, B. G., \& Nurlaelah, E. (2019). Improving Students' 
mathematical creative thinking ability through problem-based learning. Journal of Physics: Conference Series, 1280(4), 42024. https://doi.org/10.1088/17426596/1280/4/042024

Suryadi, D. (2013). Didactical design research (DDR) to improve the teaching of mathematics. Far East Journal of Mathematical Education, 10(1), 91-107. Retrieved from http://www.pphmj.com/journals/articles/1036.htm

Wardani, S., Sumarmo, U., \& Nishitani, I. (2011). Mathematical CreativityandDisposition. 群馬大学教育学部紀要 自然科学編, 59,1-16. Retrieved from https://gair.media.gunmau.ac.jp/dspace/bitstream/10087/6054/1/01_NISHITANI.pdf

Widada, W., Herawaty, D., Jumri, R., Zulfadli, Z., \& Damara, B. E. P. (2019). The influence of the inquiry learning model and the Bengkulu ethnomathematics toward the ability of mathematical representation. Journal of Physics: Conference Series, 1318(1), 12085. https://doi.org/10.1088/1742-6596/1318/1/012085

Wilson, T. D., Dunn, D. S., Kraft, D., \& Lisle, D. J. (1989). Introspection, attitude change, and attitude-behavior consistency: The disruptive effects of explaining why we feel the way we do. In Advances in experimental social psychology, 22, 287-343. Elsevier. https://doi.org/10.1016/S0065-2601(08)60311-1

Yackel, E., \& Cobb, P. (1996). Sociomathematical norms, argumentation, and autonomy in mathematics. Journal for Research in Mathematics Education, 458-477. https://doi.org/10.2307/749877

Yaman, H., Dündar, S., \& Ayvaz, Ü. (2017). Achievement motivation of primary mathematics education teacher candidates according to their cognitive styles and motivation styles. International Electronic Journal of Elementary Education, 7(2), 125142. Retrieved from https://www.iejee.com/index.php/IEJEE/article/view/70 